Abstracta Iranica Abstracta Iranica

Revue bibliographique pour le domaine irano-aryen

Volume 27 | 2006

Comptes rendus des publications de 2004

\title{
« Al-Samaw'al versus al-Kūhī on the Depression of the Horizon ». Centaurus, 45 (2003), pp. 116-129.
}

\section{Benno van Dalen}

\section{(2) OpenEdition}

1 Journals

\section{Édition électronique}

URL : http://journals.openedition.org/abstractairanica/6306

DOI : 10.4000/abstractairanica.6306

ISSN : 1961-960X

Éditeur :

CNRS (UMR 7528 Mondes iraniens et indiens), Éditions de l'IFRI

\section{Édition imprimée}

Date de publication : 15 mai 2006

ISSN : 0240-8910

Référence électronique

Benno van Dalen, « «Al-Samaw'al versus al-Kūhī on the Depression of the Horizon ». Centaurus, 45 (2003), pp. 116-129. », Abstracta Iranica [En ligne], Volume 27 | 2006, document 288, mis en ligne le 02 janvier 2007, consulté le 25 septembre 2020. URL : http://journals.openedition.org/abstractairanica/ 6306 ; DOI : https://doi.org/10.4000/abstractairanica.6306

Ce document a été généré automatiquement le 25 septembre 2020.

Tous droits réservés 


\title{
« Al-Samaw'al versus al-Kūhī on the Depression of the Horizon $»$. Centaurus, 45 (2003), pp. 116-129.
}

\author{
Benno van Dalen
}

What is Seen of Sky and Sea (edited and translated by Rashed in Arabic Sciences and Philosophy, 11 (2001), pp. 157-204) is one of only very few treatises by the 10th century geometer Abū Sahl al-Kūhī that deals with topics outside of mathematics proper, namely the area of the surface of the sea and the part of an altitude circle that can be seen by an observer at the top of a tower on an island. Al-Kūhi's method is criticized by the 12th century physician Ibn Yahyā al-Samaw'al al-Maghribī, who spent the last part of his life near Marāgha after having traveled extensively, in his important but mostly unstudied work The Exposure of the Errors of the Astronomers. The authors discuss alSamaw'al's criticisms and describe his computational alternative to al-Kūhī's geometrical method in detail. They also present an edition of the Arabic passages concerned together with an English translation.

INDEX

Thèmes : 10. Histoire des Sciences et des Techniques 


\section{AUTEURS}

BENNO VAN DALEN

J. W. Goethe-Universität - Frankfurt 